\title{
The Evolution Of Risk Premiums In Emerging Stock Markets: The Case Of Latin America And Asia Region
}

Salma Fattoum, INSEEC Business School, France

Khaled Guesmi, IPAG Business School, EconomiX, \& University of Paris Ouest Nanterre La Defense, France Bruno-Laurent Moschetto, IPAG Business School, France

\begin{abstract}
This paper employs a conditional version of the International Capital Asset Pricing Model (ICAPM) to investigate the determinants of regional integration of stock markets in Latin America and Asia over the period 1996-2008. This model allows for three sources of time-varying risks: common international market risk, exchange rate risk, and regional market risk. At the empirical level, we make use of the asymmetric multivariate BEKK-GARCH of Baba et al.'s (1990) process to simultaneously estimate the ICAPM. Our results show that the currency risk premium is the most important component of the total premium followed by the global market premium. As for the regional risk, our findings show that it is significantly priced for our studied emerging regions but its contribution to the total risk premium is weak.
\end{abstract}

Keywords: ICAPM; Stock Market Integration; Exchange Rate Risk

\section{INTRODUCTION}

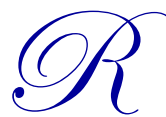

egional and cooperation has been strengthened in the last decades and regional integration has now become an incontestable trend thanks to its theoretical expected advantages. Regional integration may offer to national emerging stock markets ways to overcome some of the obstacles constraining their development. Possible benefits associated with regional integration of exchanges are more possibilities of diversification of risks in more efficient and competitive markets, and lower costs. By combining the resources of fledgling and fragmented capital markets, regionalization could boost liquidity and the ability of these markets to mobilize local and international capital for infrastructural development. Investors would gain access to a broader range of shares. There may also be a role for a well-functioning regional exchange in preventing large capital outflows from the region. Moreover, progress toward integration of capital markets on a regional basis may actually help spur accelerated economic integration goals in other areas.

We estimate a multivariate version of BEKK-GARCH of Baba, Engle, Kraft, and Kroner (1990) to specify the contribution of each risk factor to the total premium. The model is estimated for the period March 1996-June 2008, simultaneously for 3 market regions: the world market and two emerging zones: Asia (Malaysia, Singapore, Sri Lanka, Indonesia, and Thailand), and Latin America (Venzuela, Chile, Brazil, Argentina, and Mexico).

Our results show that global equity risk premium in Asia and Latin America is determined by three risk factors: global factors, regional factors, and currency risk. The relative contributions of these factors to the total risk premium vary across regions as well as over time according to stock and currency market stability.

The paper is organized as follows. Section 2 describes the conditional version of the International Capital Asset Pricing Model (ICAPM) where both world market risk and regional risk are priced. Section 3 presents the data. The results are reported in Section 4. Section 5 concludes. 


\section{THE MODEL}

Under the assumption of purchasing power parity (PPP) and perfect integration, the international version of the CAPM of Sharpe (1964) and Lintner (1965) predicts that excess expected return on a security is priced with respect to the regional market risk factor, usually represented by the stochastic fluctuations of a world market portfolio. In this article, we extend the well-known one-factor ICAPM to the case of partial integration with three sources of systematic risk that reflect changes in regional stock market, domestic stock market, and real exchange rate. We estimate the following empirical international asset pricing model in which expected risk premium of country $\mathrm{i}, X_{c, t}$ is determined by the regional market excess return, $X_{m, t}$, the exchange rate return, $X_{k, t}$, and the residual regional return, $\operatorname{var}\left(\theta_{i t}\right)$ :

$x_{c, t}=e^{\left(\delta_{m}^{\prime} M_{m, t-1}\right)} \operatorname{Cov}\left(x_{c, t}, x_{m, t}\right)+e^{\left(\delta_{k}^{\prime} M_{k, t-1}\right)} \operatorname{Cov}\left(x_{c, t}, x_{k, t}\right)+e^{\left(\gamma_{c}^{\prime} R_{c, t-1}\right)} \operatorname{var}\left(\theta_{c, t}\right)$

All returns are expressed in the same reference currency, the American dollar.

$e^{\left(\delta_{m}^{\prime} M_{m, t-1}\right)}$ and $e^{\left(\gamma_{i}^{\prime} R_{i, t-1}\right)}$ denote the regional and domestic prices of risk respectively. The evidence in Harvey (1991) and De Santis and Gerard (1997) suggests that the price of risk is time varying. Furthermore, Merton (1980) and Adler and Dumas (1983) show the price of market risk to be equal to the world aggregate risk aversion coefficient. Since most investors are risk averse, the price of risk must be positive. In this paper, we follow De Santis and Gerard (1997), De Santis et al. (2003) and Gerard et al. (2003) and model the dynamics of the risk prices as a positive function of regional information variables $\left(M_{m, t-1}\right.$ for $\left.e^{\left(\delta_{m}^{\prime} M_{m, t-1}\right)}\right)$ and regional information variables $\left(R_{i, t}\right.$ for $\left.e^{\left(\gamma_{i}^{\prime} R_{i, t-1}\right)}\right)$.

Concerning the price of currency risk $e^{\left(\delta_{k}^{\prime} M_{k, t-1}\right)}$, the theory does not impose any restrictions on its sign. This is because investors might in fact be willing to attach a negative price to a currency deposit if the expected excess return is negative and the currency return covaries positively with the market portfolio. We thus adopt a linear specification to model the currency price risk based on information contained in $M_{k, t-1}, \operatorname{var}\left(\theta_{i t}\right)$ captures the domestic market undiversifiable risk uncorrelated to world risk. We measure this regional risk by:

$$
\begin{aligned}
& \operatorname{Var}\left(\theta_{i t}\right)=\left(\frac{\operatorname{Cov}\left(x_{m t}, x_{i, t}\right)}{\operatorname{Var}\left(x_{m t}\right)}\right)^{2} \operatorname{Var}\left(x_{m t}\right)+\left(\frac{\operatorname{Cov}\left(x_{k t}, x_{i, t}\right)}{\operatorname{Var}\left(x_{k t}\right)}\right)^{2} \operatorname{Var}\left(x_{k t}\right) \\
& +2\left(\frac{\operatorname{Cov}\left(x_{m t}, x_{i, t}\right)}{\operatorname{Var}\left(x_{m t}\right)}\right)\left(\frac{\operatorname{Cov}\left(r_{k t}, x_{i, t}\right)}{\operatorname{Var}\left(x_{k t}^{c}\right)}\right) \operatorname{Var}\left(x_{m t}, x_{k t}\right)-2 \frac{\operatorname{Cov}\left(x_{m t}, x_{i, t}\right)^{2}}{\operatorname{Var}\left(x_{m t}\right)}-2 \frac{\operatorname{Cov}\left(x_{k t}, x_{i, t}\right)^{2}}{\operatorname{Var}\left(x_{k t}\right)} \\
& =\operatorname{Var}\left(x_{i, t}\right)-\frac{\operatorname{Cov}\left(x_{m, t}, x_{i, t}\right)^{2}}{\operatorname{Var}\left(x_{m, t}\right)}-\frac{\operatorname{Cov}\left(x_{k, t}, x_{i, t}\right)^{2}}{\operatorname{Var}\left(x_{k, t}\right)}+2 \frac{\operatorname{Cov}\left(x_{k t}, x_{i, t}\right) \operatorname{Cov}\left(x_{m t}, x_{i, t}\right) \operatorname{Cov}\left(x_{m t}, x_{k, t}\right)}{\operatorname{Var}\left(x_{m, t}\right) \operatorname{Var}\left(x_{k t}\right)}
\end{aligned}
$$

Furthermore, Equation 1 can be written as a risk premium decomposition. More specifically, the total risk premium (PRT) can be broken down into three components.

$$
P R T_{i, t}=P R W_{i, t}+P R C_{i, t}+P R D_{i, t}
$$

Where the first component is called the world risk premium (PRW), and is given by: $P R W_{i, t}=e^{\left(\delta^{\prime} M_{m, t-1}\right)} \operatorname{Cov}\left(x_{c, t}, x_{m, t}\right)$. The second one is the exchange rate risk premium (PRC) expressed as 
follows: $P R C_{i t}=e^{\left(\delta_{k}^{\prime} M_{k, t-1}\right)} \operatorname{Cov}\left(x_{c, t}, x_{k, t}\right)$ and the third one refers to the domestic risk premium (PRD), written as: $P R D_{i t}=e^{\left(\gamma_{c} R_{c, t-1}\right)} \operatorname{var}\left(\theta_{c, t}\right)$.

Next, consider the econometric methodology. Under rational expectations, we assume errors follow a $\operatorname{GARCH}(1,1)$ specification and write the model as follows:

$$
\left\{\begin{array}{l}
x_{t}=\eta_{m, t-1} h_{m, t}+\eta_{k, t-1} h_{k, t}+\eta_{d, t-1} \operatorname{Var}_{t}+\varepsilon_{t} \\
\varepsilon_{t} \mid \psi_{t-1} \sim N\left(0, H_{t}\right) \\
H_{t}=H_{0} *\left(\tau \tau^{\prime}-a a^{\prime}-b b^{\prime}\right)+a a^{\prime} * \varepsilon_{t-1} \varepsilon_{t-1}{ }^{\prime}+b b^{\prime} * H_{t-1}
\end{array}\right.
$$

$H_{t}$ is the conditional covariance matrix of returns, $h_{m, t}$ and $h_{k, t}$ are the conditional covariance between the considered zone equity returns and the world market and the different exchange rate returns respectively. $H_{0}$ is the unconditional variance. $\operatorname{Var}_{t}$ is the vector of residual regional risks can be written as:

$$
\left\{\begin{array}{l}
\operatorname{Var}_{t}=\operatorname{diag}\left(H_{t}\right)-h_{m, t}^{2} / h_{m m, t}-h_{k, t}^{2} / h_{k k, t}+2\left(h_{m, t} * h_{k, t} * h_{m k, t}\right) /\left(h_{m m, t} * h_{k k, t}\right) \\
\operatorname{diag}\left(H_{t}\right)=\operatorname{diag}\left(\sqrt{h_{11, t}}, \ldots, \sqrt{h_{m n, t}}\right)
\end{array}\right.
$$

$h_{m m, t}$ and $h_{k k, t}$ the variances of the world market return and the exchange rate $\mathrm{k}$ return. In the system (3), there are 9 equations: five equations to model the expected risk premium for the world equity market and the four studied emerging zones, and four equations to model the expected excess returns of the aggregate exchange rates of the four studied emerging zones against American dollar. To avoid incorrect inference due to the misspecification of the conditional density of asset returns, the quasi-maximum likelihood (QML) approach of Bollerslev and Wooldridge (1992) is used.

\section{DATA}

This study investigates the global integration process of emerging market regions: Asia (Malaysia, Singapore, Sri Lanka, Indonesia, and Thailand) and Latin America (Venezuela, Chile, Brazil, Argentina, and Mexico).

Monthly data are collected for regional stock market indices, world stock market index, and real effective exchange rate indices over the period from March 31, 1996 to March 31, 2008. Our sample excludes the episodes of the last Global Financial Crisis that could generate biased estimates. Data are obtained from Thomson Datastream International, the IMF's International Financial Statistics (IFS) and the U.S. Federal Reserve databases.

\subsection{Stock Market Returns and Real Exchange Rate Indices}

We use the Morgan Stanley Capital International (MSCI) World Market Index, which is the value-weighted global market index consisting of the 21-national indices, as a proxy for the global market. For each of the four regions, index returns corresponds to the geometric mean of stock returns weighted by market capitalization of each member country. The returns on world market and on each country index are computed from taking the difference in logarithm between two consecutive index prices. All returns are expressed in US dollars and are converted into excess returns by subtracting the one-month Eurodollar interest rate, taken as the risk-free rate in our study. The Eurodollar rate is obtained from Datastream International database. 
We use the real effective exchange rate (REER) indices to represent exchange rate risk since variations in inflation rates of emerging countries are more significant in comparison to those in exchange rates. For each emerging region, the REER index is measured by the geometric weighted average of all individual countries' exchange rates against the US dollar, where the weights are the share of each country in the foreign trade with the United States. These indices are calculated monthly by using exchange rate and trade data from Datastream International, the Federal Reserve Bank of St Louis, and the IMF's International Financial Statistics.

\subsection{Information Variables}

Following Hardouvelis et al. (2006) and Carrieri et al. (2007), we employ the following global variables: the dividend yield of the world market portfolio (MSCI World index) in excess of the 1-month Eurodollar interest rate which is denoted by (DYW), the variation in the US term premium (VUS), the return on the S\&P's 500 stock market index (SPV), and the variation in the 1-month US Treasury bill yield (TBY). Data concerning these information variables are obtained from MSCI and the IMF's International Financial Statistics databases.

The regional instrumental variables include the dividend yield of a regional market portfolio (RPD), the return on the regional stock market index in excess of the 30-day Eurodollar interest rate (RTI), and the variation in the trade-weighted average regional inflation rate (INV). Data are extracted from MSCI and Datastream International.

\subsection{Stochastic Properties of the Data}

Table 1 indicates that the skewness coefficients are positive for Latin America and negative for Asia. They are significantly different from zero, indicating the presence of asymmetry in the return distribution. In addition, all the return series are characterized by a kurtosis coefficient statistically significant and greater than 3 , and thus have fatter tails than those of a normal distribution. The findings from Jarque-Bera test, not presented here for concision purpose, confirm the rejection of normality.

Table 1: Descriptive Statistics of Return Series

\begin{tabular}{|c|c|c|c|c|c|c|}
\hline & Mean & Std. dev. & Skewness & Kurtosis & J.B. & ARCH (6) \\
\hline \multicolumn{7}{|c|}{ Panel A: Returns on Real Exchange Rate Indices } \\
\hline Latin America & 0.023 & 3.223 & -0.712 & 5.416 & $27.702^{+++}$ & $58.118^{+++}$ \\
\hline Asia & 0.154 & 2.221 & -0.301 & 7.339 & $31.241^{+++}$ & $71.181^{+++}$ \\
\hline \multicolumn{7}{|c|}{ Panel B: Excess Returns on Regional Stock Market Indices } \\
\hline Latin America & 3.003 & 11.041 & 0.801 & 9.001 & $89.124^{+++}$ & $17.145^{++}$ \\
\hline Asia & 2.987 & 8.098 & -0.812 & 8.057 & $122.916^{+++}$ & $22.044^{+++}$ \\
\hline
\end{tabular}

\section{EMPIRICAL RESULTS}

Panel A of Table 2 presents the estimated parameters for the price of foreign exchange risk associated with fluctuations of each of the two regional trade-weighted real exchange rate. We first observe that they are mainly driven by the S\&P's 500 index returns, and the change in the yield of the 1-month US treasury bills because the associated coefficients are statistically significant at the conventional levels.

Table 2: Prices of World Market, Real Exchange Rate and Regional Market Risks

\begin{tabular}{lccccc}
\hline \multicolumn{7}{c}{ Constant } & DYW & VUS & VUS & TBY \\
\hline \multicolumn{2}{l}{ Panel A: Price of Exchange Rate Risk } & & & & \\
\hline \multirow{2}{*}{ Latin A. } & $0.466^{* * *}$ & $4.101^{* * *}$ & -0.022 & $31.022^{*}$ & $6.529 * * *$ \\
& $(0.005)$ & $(1.761)$ & $(0.051)$ & $(3.336)$ & $(0.403)$ \\
\multirow{2}{*}{ Asia } & $0.572^{* * *}$ & 0.601 & $0.191 * * *$ & $12.205^{*}$ & $3.761^{* * *}$ \\
& $(0.021)$ & $(0.509)$ & $(0.013)$ & $(0.439)$ & $(0.384)$ \\
\hline \multicolumn{2}{l}{ Panel B: Price of World Market Risk } & & & & \\
\hline \multirow{2}{*}{ World } & $0.888^{* * *}$ & $20.132^{* * *}$ & $-0.251^{* * *}$ & $7.610^{* * *}$ & 0.351 \\
& $(0.025)$ & $(4.218)$ & $(0.031)$ & $(1.348)$ & $(1.329)$ \\
\hline
\end{tabular}

Copyright by author(s); CC-BY 

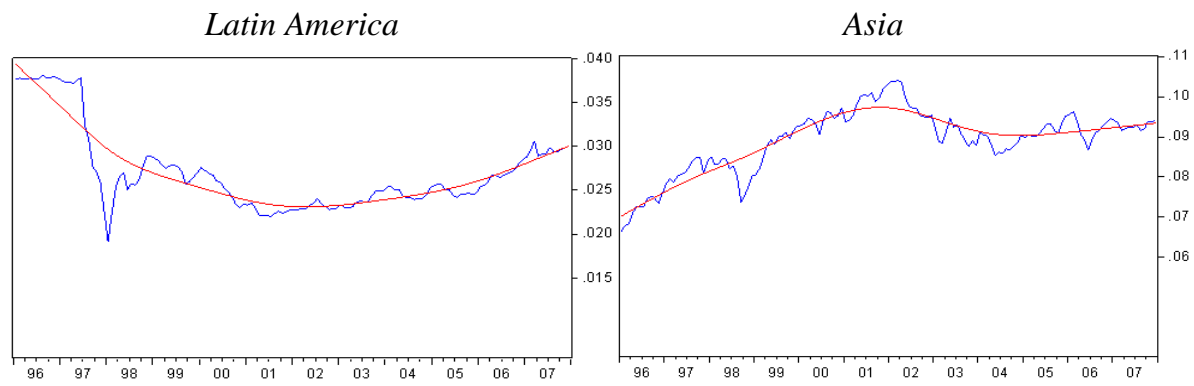

Figure 1: Currency Risk Prices

The filtered series reported in Figure 1 shows a considerable reduction of the risk at the beginning of the years 2000 and 2005. The highest values are recorded in 2002 and 2003 after the terrorist attacks against the United States and a second drop from the year 2006. The price of world market risk is very volatile especially in the late 1990's and after 2001. The HP filtered series reveals two phases of expansion: in 1999 and from 2002 until the end of the study period. In this second phase, the change is much more significant compared to the years 1997-1998, reflecting the uncertainty across global financial markets in recent years. Next consider the prices of regional residual risks. The inclusion of these risks can be interpreted as a measure of mild segmentation or as an average measure of other factors that cannot be captured by the model like differential tax treatment. However as shown in Figure 2 the dynamics of regional prices of risk are different depending on regional specific factors.

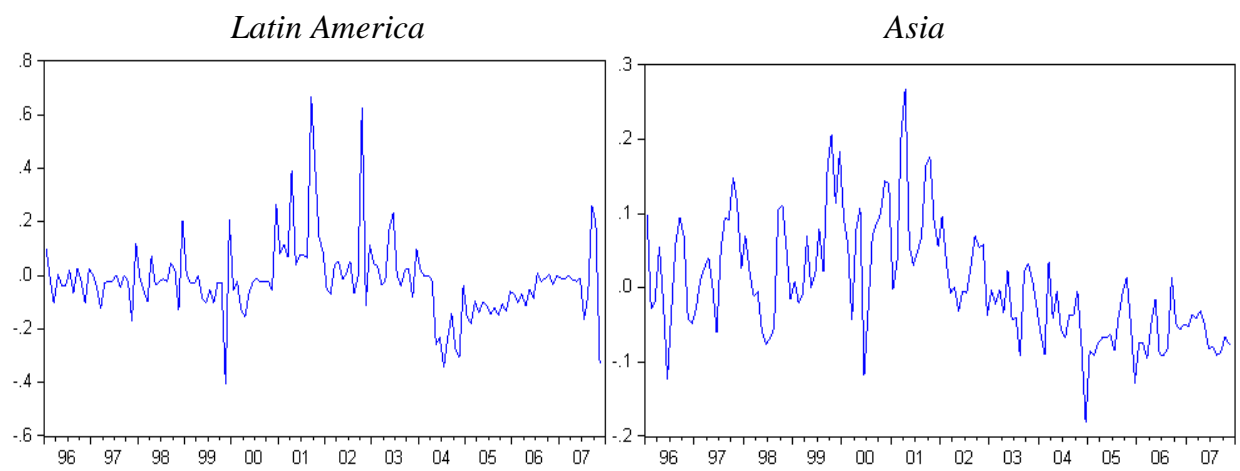

Figure 2: Prices of the Regional Risk

As for regional residual risk premiums (Table 3), they are significant for our studied emerging regions confirming that these regions are partially segmented from world markets. In addition, the exchange risk premium is the most significant component of the total premium. Our results confirm those of Arouri (2006) and Guesmi (2012) who shows that currency risk (Figure 3) is the most important risk factor in Latin America over the period 19902000. For Asia, the total risk premium initially knows very high values during the financial crisis of 1997-1999, and shows a subsequent increase in the years 2001, 2002, and 2007. The exchange risk premium is the main component of total risk premium during the sub-period 1996-2001, suggesting that during this period the dynamics of expected returns is better explained by exchange rate risk than the world global risk.

Table 3: Decomposition of the Total Risk Premium

\begin{tabular}{lcccc}
\hline & PRMR & PRMW & PRMCH & PRMT \\
\hline \multirow{2}{*}{ Latin America } & $0,322^{* * *}$ & $4.292^{* * *}$ & $5.213^{* * *}$ & $10.532^{* * *}$ \\
& $(0.000)$ & $(0.000)$ & $(0.000)$ & $(0.000)$ \\
\hline \multirow{2}{*}{ Asia } & $0.768^{* * *}$ & $4.145^{* * *}$ & $9.105^{* * *}$ & $14.520^{* * *}$ \\
& $(0.320)$ & $(0.000)$ & $(0.000)$ & $(0.000)$ \\
\hline \multirow{2}{*}{ World } & - & $6.751^{* * *}$ & $-2.400^{* * *}$ & $4.351 * * *$ \\
& & $(0.000)$ & $(0.000)$ & $(0.000)$ \\
\hline
\end{tabular}

${ }^{+++}$indicates that the average risk premiums are significantly different from zero at the $1 \%$ level with respect to the two-sided Student-t test. 
Asia

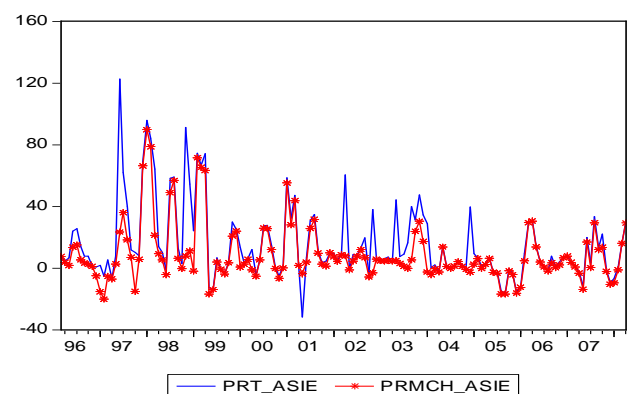

Latin America

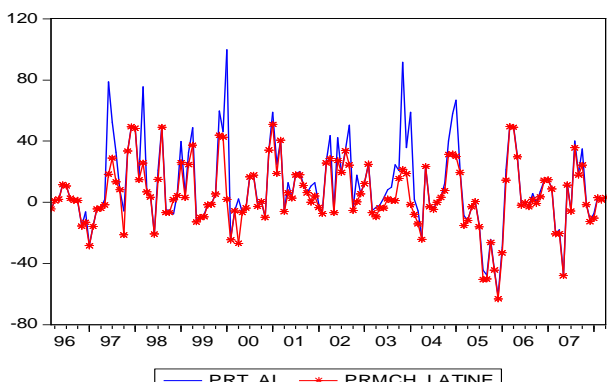

Figure 3: Evolution of Risk Premiums

\section{CONCLUSION}

In this paper we analyzed the formation of the international risk premium in two emerging market regions, Latin America and Asia. The use of the segmentation version of ICAPM presents many advantages, in particular, it takes into account the phenomenon of partial segmentation and allows the prices and quantities of risk to vary over time. Our results show that emerging regions are partially segmented from world stock markets and the risk premium in emerging zones depends significantly on both global, exchange rate and regional risk factors.

\section{AUTHOR INFORMATION}

Salma Fattoum, PhD, is an Associate Professor at INSEEC Business School at the Department of Management in Lyon, France. Her PhD deals with the attitudes of successors joining the family firm and the role the predecessor plays in the integration phase. Dr. Fattoum has previously published in Journal of Enterprising Culture, Economic Modelling, and Journal of Applied Business Research. E-mail: sfattoum@inseec.com (Corresponding author)

Khaled Guesmi, PhD, is an Associate Professor of Finance at IPAG Business School. He is also an Associate Researcher at Economix, University of Paris Ouest Nanterre la Défense. His principal research areas concern finance in emerging markets. His most recent articles are forthcoming and published in refereed journals such as Economic Modelling, Energy Economics, Economics Bulletin, Journal of Banking and Finance, Applied Economics, Journal of Applied Business Research, Energy Study Review, Journal of International Financial Markets, Institutions \& Money... E-mail: khaled.guesmi@ipag.fr

Bruno Laurent Moschetto, PhD in Management from the University of Paris IX-Dauphine. Bruno Lawrence Moschetto is a lecturer at the IAE of Valenciennes and a professor at the Graduate School of Business of Amiens where he hosts a seminar on design of the business plan. He also serves as a consultant and develops tools for decision support specifically dedicated to small and medium structures.

\section{REFERENCES}

1. Adler, M., \& Qi, R. (2003). Mexico's integration into the North American capital market. Emerging Economic Review, 4, 91-120.

2. Arouri, M. (2006). Are stock markets integrated? Evidence from a partially segmented ICAPM with asymmetric effects. Frontiers of Finance and Economics, 2, 70-94.

3. Baba, Y., Engle, R. F., Kraft, D. F., \& Kroner, K. (1990). Multivariate simultaneous generalized ARCH. San Diego: Department of Economics, University of California.

4. Bollerslev, T., \& Wooldrige, J. M. (1992). Quasi-maximum likelihood estimation and infrence in dynamic models with time-varying covariances. Econometric Review, 11, 143-172.

5. Berndt G., Hall, B., Hall, R., \& Hausmann, J. (1974). Estimation and inference in nonlinear structural models. Annals of Economics and Social Measurement, 3, 653-665. 
6. Carrieri, F. (2001). The effects of liberalization on market and currency risk in the European Union. European Financial Management, 7, 259-290.

7. Carrieri, F., Errunza, V., \& Hogan, K. (2007). Characterizing world market integration through time. Journal of Financial and Quantitative Analysis, 42, 915-940.

8. De Santis, G., \& Imrohoroglu, S. (1997). Stock returns and volatility in emerging financial markets. Journal of International Money and Finance, 16(4), 561-579.

9. De Santis, G., Gerard, B., \& Hillion, P. (2003). The relevance of currency risk in the EMU. Journal of Economics and Business, 55, 427-462.

10. Engle, R. (1982). Autoregressive conditional heteroskedasticity with estimates of the variance of U.K Inflation. Econometrica, 50, 987-1008.

11. Errunza, V., \& Losq, E. (1985). International asset pricing under mild segmentation: Theory and test. Journal of Finance, 40, 105-124.

12. Gerard, B., Thanyalakpark, K., \& Batten, J. (2003). Are the East Asian markets integrated? Journal of Economics and Business, 55, 585-607.

13. Guesmi K. (2012). Characterizing South-East Asian stock market integration through time. International Journal of Business, 17(1), 100-112.

14. Hardouvelis, G., Malliaropoulos, \& Priestley, D. (2006). EMU and stock market integration. Journal of Business, 79, 365-392.

15. Harvey, C. R (1995). The risk exposure of emerging equity markets. World Bank Economic Review, 9, 1950 .

16. Harvey, C. R (1991). The world price of covariance risk. Journal of Finance, 46, 111-157.

17. Hodrick, R., \& Prescott, E. (1997). Post war US business cycles: A descriptive empirical investigation. Journal of Money, Credit and Banking, 29(1), 1-16.

18. Merton, R. C. (1973). An intertemporel capital asset pricing model. Econometrica, 41(5), 867-887.

19. Pukthuanthong, K., \& Roll, R. (2009). Global market integration: An alternative measure and its application. Journal of Financial Economics, 94, 214-232.

20. Sharpe, W. (1964). Capital asset prices: A theory of market equilibrium under conditions of risk. Journal of Finance, 9, 725-742. 


\section{NOTES}

